\title{
Pemberdayaan \\ Hak-hak Rakyat atas Tanah ${ }^{*}$
}

\author{
Masyhud Asyhari
}

\begin{abstract}
The principles of the establishment of the national agrarian law had been formed by the old Order Regime. The law, conceptually, aims to create prosperous society, especially villagers, on the basis of Pancasila (the Five Principle State (deology), the 1945 Constitution. The real policies of the Old Order Regime to create prosperous society had been issued, however, its implementation had not been optimum. Yet in the New Order Regime, the land rights of societies were often ignored, and even admitted, if these are being faced with the interest of capital owners. Finally, the society hope, in this reformation era, that their rights on the land can be certainly legalized through the enforcement process of socity rights on land.
\end{abstract}

\section{Pendahuluan}

Tanah dalam kehidupan manusia mempunyai arti yang sangat penting baik untuk kehidupan maupun tempat peristirahatan terakhirnya. S:elain mempunyai arti penting bagi manuşa, taniah juga mempunyai kedudukan yang strategis bagi pembangunan bangsa. Oleh karenäituringingingat strategisnya fungsi tanah, maka diundangkanlah UU No. 5 Tahun 1960 tentang Peraturan Dasar PokokPokok Agraria atau lebih dikenal dengan UUPA pada tanggal 24 September 1960.' Kehadiran
Undang-undang ini bertujuan untuk menciptakan adanya unifikasi hukum tanah secara nasional. Untuk mensosialisasikan UU tersebut tanggal kelahirannya selalu diperingati oleh bangsa Indonesia sebagai hari kemenangan bangsa Indonesia pada umumnya, dan rakyat tani pada khususnya. Selain itu kehadiran UUPA juga sebagai bukti bahwa bangsa Indonesia bisa melepaskan diri dari pengaruh penjajah kolonial Belanda. Dengan lahirnya UUPA, maka berlakulah unifikasi hukum pertanahan

"Tulisan ini dapat dipublikasi berkat saran-saran yang diberikan oleh peserta diskusi Departemen HAN, FH UII. dan juga atas nama Jawahir Thontowi. SH. PhD. Atas segala kebaikannya penulis ucapkan terima kasih.

UU No. 5 Tahun 1960 tentang Peraturan Dasar Pokok-pokokAgraria selanjutnya disebut UUPA. 
nasional yang sebelumnya bersifat dualistis/ pluralistis. Konsekuensi yuridisnya adalah seluruh masyarakat Indonesia wajib mematuhi UUPA tersebut.

Akan tetapi dalam realitas pelaksanaan UUPA ini acapkali mengalami hambatan. Esensi keadilan bagi rakyat yang diperjuangkan dalam UUPA tersebut tidak tercapai. Oleh karena baik dalam masa pemerintahan Orde Lama maupun Orde Baru fungsi tanah telah dijadikan obyek penting dalam pembangunan ekonomi. Di satu pihak, penanaman modal dalam dan luar negeri telah diuntungkan, sementara rakyat umumnya telah menjadi korban.

Tulisan ini akan berusaha menjawab persoalan benarkah UUPA dilahirkan mengandung nilai-nilai kerakyatan dan keadilan sosial. Beberapa aspek penting seperti asas nasionalitas, asas pengakuan hak ulayat, dan asas fungsi sosial menjadi bagian penting yang perlu dikemukakan.

\section{Asas Nasionalitas}

Asas ini memberikan pengertian bahwa seluruh bumi (tanah) air dan ruang angkasa dalam wilayah Republik Indonesia merupakan kekayaan alam milik bangsa Indonesia. Secara keseluruhan dipergunakan untuk kemakmuran bersama bangsa Indonesia dan tidak diperkenankan Warga Negara Asing untuk menguasai tanah dengan hak apapun.
Maka hak menguasai atas tanah tersebut diberikan kepada Negara sebagai organisasi tertinggi rakyat dengan cara mengatur berbagai hubungan hukum antara orang dengan tanah. (Pasal 1 ayat (2) UUPA). Asas hukum seperti ini tidak saja memberikan pengaturan hubungan antara negara dengan warganegara dalam penguasaan tanah, melainkan juga memberikan pengakuan terhadap kedudukan tanah sebagai sumber perekonomian negara. ${ }^{2}$ Artinya dalam batas tertentu, warga negara memiliki hak untuk menguasai tanah sebagai Hak Milik atau Hak Guna Bangunan (HGB) atau Hak Guna Usaha selagi negara secara tegas mengaturnya.

\section{Asas Pengakuan Hak Ulayat dan Hak Pribadi}

Asas ini dengan tegas mengakui eksistensi hak masyarakat adat atas tanah, demikian juga perseorangan atau badan hukum dapat mempunyai hak atas tanah untuk keperluan pribadi maupun usahanya (Pasal 3 dan 4 UUPA). Pengakuan terhadap hak ulayat menunjukan adanya kebolehan warga negara, secara adat untuk memiliki atau menguasai tanah secara kolektif bagi terpenuhinya kepentingan bersama. Namun, juga pengakuan hak atas tanah secara pribadi diperkenankan. Tentu hal ini berbeda model kepemilikan tanah di negara-negara Sosialis Komunis. ${ }^{3}$ Sebab di negara-negara komunis

"Lihat Parlindungan Hukum Agraria. Beberapa Pemikiran dan Gagasan. Hermawan Sauni (ed) 1998. Medan: USU. Him. 98.

'Budi Harsono. 1994. Hukum Agraria Indonesia; Sejarah Pembentukan UUPAlsi dan Pelaksanaannya. Jakarta: Djambatan. 
pemilikan kolektif menjadi ciri utama. Peranan negara begitu penting sebagai pengatur dan penguasa atas tanah-tanah.

Pengakuan hak ulayat dan pribadi yang diperkenankan oleh UUPA harus mencerminkan situasi tersebut. Di Yogyakarta, hak ulayat misalnya berupa tanah desa atau tanah kas desa. Bahkan hak ulayat dikatakan sebagai hak tertinggi dalam masyarakat hukum. Jadi hak ulayat lebih merupakan pemilikan atas tanah secara bersama.

Selain tanah hak ulayat juga dikenal tanah yang diakui eksistensinya secara hukum adat. Ciri-ciri hukum tanah dat antara lain: tanah tempat tinggal, tanah yang menjadi sumber kegiatan ekonomi, tanah yang berkaitan penggunaannya dengan keagamaan, dan tanah yang ada hubungannya dengan kegiatan sosial. ${ }^{4}$ dari ciri-ciri hukum tanah adat jelas mengakui adanya hak-hak pribadi.

Sistem pemilikan secara adat juga diakui dengan atribut-atribut sebagi berikut. Atribut sosial, mistis dan religius adalah melekat pada tanah adat. Sementara itu, dalam sistem pemilikan adat, hak-hak individual dapat diperoleh melalui asal usul di mana si pemilik adalah anggota persekutuan masyarakat, sebagai pengguna saja. Sedangkan kedua, pemilikan tanah secara individual bisa terjadi setelah ada pengalihan dari satu kelompok lain. ${ }^{5}$

\section{Asas Fungsi Sosial}

Asas ini mempunyai arti bahwa semua hak-hak atas tanah di samping memberikan manfaat bagi pemegang haknya juga harus memberikan manfaat bagi masyarakat. (Pasal 6 UUPA). Di samping itu fungsi sosial ini mengandung pengertian bahwa tanah harus digunakan sesuai dengan hak yang membebaninya. Karena itu, model kepemilikan benda-benda termasuk tanah jelas berbeda dengan apa yang diatur dalam Kitab Hukum Undang-undang Perdata (KUHPrdt). asas fungsi sosial sebenarnya muncul sebagai respon terhadap konsep hukum pemilikan/konsep hukum penguasaan absolut. Sementara dalam tradisi hukum Indonesia lebih memilih asas pemilikan yang relatif. Artinya negara mengakui pemilikan atas tanah secara individual. Tetapi, jika negara memandang bahwa tanah tersebut memiliki nilai guna bagi kepentingan umum, maka bisa saja negara secara hukum memindahkan penguasaan hak itu melalui suatu konpensasi yang adil.

Dalam praktik, lahirnya Keppres No. 5 Tahun 1993, adalah salah satu instrumen hukum yang dapat dengan mudah menyelewengkan peranan kewenangan negara untuk mengambil alih hak-hak rakyat atas tanah dengan alasan kepentingan umum. ${ }^{6}$

${ }^{4}$ Lihat lebih lanjut. Hadisuprapto. 1977. Ikhtisar Perkembangan Hukum Tanah DIY: Yogyakarta: Karya Kencana. HIm. 3.

${ }^{5}$ Secara panjang lebar dibahas secara komprehensif oleh Maria R Ruwiastuti, dkk. Penghancuran Hak Masyarakat Adat atas Tanah. Bandung: INPI-PACT. HIm . 8.

${ }^{6}$ Lihat penjelasan lanjutmengenai kasus pengambilalihan tanah-tanah lot di Bali. Jawahir Thontowi. "Reformasi dan Kompilasi Peraturan Hukum Kerukunan antara Umat Beragama." di dalam Hanafi Sofyan. 1995. Indonesia dalam Transisi: Canbera: Halmahera Fondation. Hlm. 168. 


\section{Asas Pemerataan/Keadilan}

Asas ini melarang pemilikan/penguasaan tanah yang berlebihan sehingga diharapkan dapat terwujud penguasaan tanah yang adil, dan tanah harus diusahakan secara aktif oleh pemiliknya, menjaga dan memeliharanya sesuai dengan asas kelestarian kualitas lingkungan hidup dan produktifitas sumber daya alam. Oleh karena itu tanah tidak boleh diperdagangkan, karena tanah bukanlah komoditi. (Pasal 7, 9, 11 UUPA). Asas pemilikan yang merata dan berkeadilan pada dasarnya merupakan manifestasi dari keinginan negara, termasuk pendiri bangsa ini. Pemilikan dan penguasaan tanah yang berlebihan termasuk menjadikan tanah sebagai komoditi dilarang oleh negara. Ketentuan ini tentu diberlakukan dalam rangka mendorong berlakunya asas pemilikan yang memiliki nilai fungsional. Akan tetapi, asas ini dalam kenyataannya tidak mudah diberlakukan. Bukti-bukti penyimpangan akan terlihat dalam perjalanan sejarah Orde Lama dan Pemerintahan Orde Baru.(Pasal ini juga lebih mempertegas kedudukan Pasal 33 UUD 1945, terutama dalam kaitannya dengan batasan kebolehan rakyat dan negara menguasai tanah untuk kepentingan nasional, dan kesejahteraan rakyat).

Sejak kelahirannya UUPA telah mengalami 3 jaman, yaitu: jaman Orde Lama Orde Baru dan Orde Reformasi. Dalam perjalanannya UUPA tidak mengalami perubahan secara substansional, namun dalam pelaksanaannya mengalami perubahan "arah" sejalan dengan strategi dan kebijakan pemerintah pada setiap periode.

Tulisan ini mencoba melihat strategi dan kebijakan pemerintah Orde Reformasi di bidang pertanahan. Namun sebelum lebih jauh perlu kiranya dikemukakan secara sepintas situasi peranan UUPA pada masa Orde Lama dan Orde Baru.

\section{Perjalanan UUPA di Zaman Orde Lama dan Orde Baru}

Tidak dapat dipungkiri bahwa UUPA Merupakan produk hukum dari Orde Lama. Sebagai produk hukum Orde Lama UUPA berisikan kebijakan penguasa pada waktu perubahan dan pembaharuan di bidang pertanahan yang menghendaki adanya serta pembangunan yang berdasarkan Pancasila dan UUD 1945.

Kebijaksanaan penguasa Orde Lama tersebut diimplementasikan dalam konsideran, pasal-pasal serta penjelasannya sebagai perwujudan dari sila-sila Pancasila dan Pasal 33 ayat (3) UUD 1945. Operasionalisasi kebijakan penguasa Orde Lama dalam UUPA tersebut ditetapkan garisgaris besar reformasi di bidang pertanahan yang pada waktu itu dikenal dengan Panca Program Agrarian Reform Indonesia, yaitu:

1. Perubahan hukum Tanah melalui percepatan unifikasi hukum yang berkonsepsi nasional, dengan menyediakan hak-hak atas tanah berbagai keperluan pemerintah, perseorangan dan badan-badan usaha sosial dan keagamaan, disertai pemberian jaminan kepastian hukum dengan penyelenggaraan pendaftaran tanah.

2. Penghapusan hak-hak asing dan konsesikonsesi kolonial atas tanah, yang dialihkan kepada pengusaha-pengusaha nasional.

3. Mengakhiri penghisapan feodal secara berangsur-angsur. 
4. Perombakan pemilikan dan pénguasaan tanah serta lembaga-lembaga hukum yang bersangkutan dengan penguasaan tanah, dalam mewujudkan pemerataan, kemakmuran dan keadilan, yang kemudian dikenal dengan program landreform.

5. Perencanaan persediaan dan peruntukan tanah serta penggunaan secara terencana, sesuai dengan daya dukung dan kemampuannya, yang kemudian dikenal dengan kegiatan penatagunaan tanah ${ }^{7}$

Dengan kata lain, kelima program kebijakan UUPA itu jelas mengandung misi pembaharuan hukum tanah dengan kesejahteraan serta keadilan telah menjadi targetnya. Selain itu UUPA menghendaki adanya penghapusan terhadap nilai-nilai hukum kolonial yang diskriminatif. Substansi UUPA yang sarat dengan nilai-nilai kerakyatan dan keadaan sosial tidak bisa dilepaskan dari keinginan penguasa Orde Lama yang ingin mewujudkan masyarakat yang sejahtera berdasarkan Pancasila dan UUD 1945.

Pembangunan Nasional dimulai dengan mengutamakan pembangunan pertanian dengan memberdayakan rakyat petani, melalui program Landreform dan Transmigrasi. Seperti, pembatasan pemilikan dan penguasaan tanah di Pulau Jawa dengan di luar Jawa sungguh berbeda. Pada masa Ordé Lama ini, politik sebagai panglima maka banyak ketentuan-ketentuan UUPA yang hanya dijadikan sebagai slogan politik belum merupakan kebijakan konkrit. Di samping itu "masa pemerintahan Orde Lama" ini juga relatif singkat.

Sebagaimana disinggung di atas, bahwa penguasa Orde Lama merombak sistem hukum lama (kolonial) dengan meletakkan dasar-dasar pembentukan hukum agraria nasional tidaklah mudah Orde Baru muncul sebagai akibat pergolakan politik pada waktu itu, yang klimaksnya dengan terjadinya $\mathrm{G} 30$ S/PKI. Relevansi dengan penguasaan tanah adalah ada kecenderungan model kepemilikan seperti terjadi di negara komunis, partai BTI salah satu parpol kétika itu yang menghendaki adanya kesamarataan dalam pemilikan dan penguasaan hak-hak kebendaan termasuk tanah."'Penguasaan Orde Baru selain mewarisi kèadaan politik yang tidak menentu juga mewarisi keadaan ekonomi yang sangat parah. Kebijakan penguasa Orde Baru diprioritaskan pada pertumbuhan ekonomi/pemulihan ekonomi. Kebijakan pemulihan ekonomi ini tidak dimulai dengan pemberdayaan rakyat tani, tetapi dengan mengundang investor asing untuk menanam modalnya di Indonesia. Untuk mewujudkan keberhasilan kebijakannya, maka dikeluarkanlah ketentuan-ketentuan hukum dengan maksud menarik investor untuk menanamkan modalnya di Indonesia. $\mathrm{Hal}$ ini terutama dengan mendirikan pabrikpabrik yang berskala ekspor, sehingga bangsa Indonesia akan melakukan perubahan dari negara agraris ke negara industri.

Pembangunan proyek-proyek industri, perumahan, jasa dan perkebunan tersebut semuanya memerlukan tanah untuk usahanya,

71998. Badan Pertanahan Nasional. Jakarta: Dasawarsa Bhumi BhaktiAdhiguna. Hlm. 50. 
dan pelaksanaan proyek-proyek ini kenyataannya banyak tanah rakyat kecil yang menjadi korban. Sejumlah kasus memperlihatkan betapa lemahnya rakyat kecil di hadapan "penguasa". Cara-cara pemaksaan, intimidasi menjadi berita yang sudah tidak mengagetkan. Kebanyakan masyarakat bersikap diam apabila sudah dihadapkan pada slogan "demi pembangunan". "demi kepentingan umum". Peranan dan fungsi hukum dengan lembaga peradilannya tidak dapat dijadikan pengayom/ pembela keadilan bagi masyarakat. DPR nyaris tidak berkutik dalam memperjuangkan hak dan nasib rakyat kecil korban pembangunan.

Kasus Waduk Kedungombo, Jawa Tengah 1990-1993, akan selalu menjadi satu pelajaran betapa penguasa kurang memperhatikan dan melindungi hak-hak rakyat. Bukan karena dalam Kasus Kedungombo tidak ada kompensasi dari pemerintah melainkan ketidakpuasan masyarakat disebabkan karena kurangnya masyarakat setempat dilibatkan dalam pengambilan putusan. Tidak sedikit pula di antara anggota masyarakat pemilik tanah tidak sampai menerima uang kompensasi, lantaran banyaknya tangan-tangan yang tidak bertanggung jawab. Hal ini terjadi karena sang penguasa dengan mudah untuk intervensi mempengaruhi lembaga-lembaga di atas. Para korban pembangunan biasanya memang tidak dapat membuktikan secara yuridis formal kepemilikannya sehingga tidak mempunyai daya tawar di hadapan "penguasa" dan investor. Hal yang sama dialami juga tanah-tanah yang dikuasai oleh masyarakat adat (hak ulayat), dalam Pemberian Hak Pengelolaan Hutan (HPH).

Praktik di atas dapat dijadikan indikator bahwa penguasa Orde Baru, demi pertumbuhan ekonomi sangat berpihak kepada para pemilik modal, baik pribumi maupun asing. Kaidahkaidah yang terkandung dalam UUPA semestinya dapat mensejahterakan/ melindungi hak-hak rakyat justru sering dipergunakan sebagai pembenar dari praktikpraktik yang tidak manusiawi dan tidak berkeadilan. Era Orde Baru yang menjadi panglima adalah lahimya produk hukum yang memperkuat pertumbuhan ekonomi. Demi pertumbuhan ekonomi, apapun dapat dilaksanakan meskipun harus mengorbankan hak rakyat serta melanggar HAM.

\section{Reformasi Agraria dan Pemberdayaan Hak-hak Rakyat atas Tanah}

Reformasi yang dilaksanakan pada dewasa ini dilandasi oleh keinginan rakyat untuk secara nyata memperoleh kedaulatannya dan menegakkan keadilan termasuk di dalamnya reformasi dalam bidang pertanahan. Reformasi di bidang pertanahan akan menjawab permasalahan sejauh mana kebijaksanaan yang berpihak kepada rakyat yang berkeadilan dan operasionalisasinya bagi seluruh lapisan masyarakat secara adil.

Pembangunan di bidang pertanahan di Indonesia sejak diundangkannya UUPA, mengalami perkembangan yang berarti, seiring dengan perkembangan dinamika kehidupan masyarakat Indonesia. Misalnya perkembangannya yang berarti dapat mewujudkan pembangunan bidang pertanahan harus mampu tercapainya fungsi bumi, air, dan ruang angkasa secara optimal untuk sebesar-besarnya kemakmuran rakyat seperti diamanatkan oleh Pasal 33 UUD 1945. Bukti bahwa usaha reformasi dalam bidang pertanahan program reformasi bidang 
pertanahan haruslah tetap berpedoman pada UUPA yang ditunjukkan kepada:

1. Melanjutkan perencanaan peraturan perundang-undangan sebagai pelaksana UUPA

2. Merancang perubahan peraturan pelaksanaan UUUPA yang tidak sesuai lagi dengan kondisi dewasa ini.

3. Merancang peraturan operasional yang bersifat deregulatif

Ketiga kehendak tersebut, tampak semakin optimis ketika wakil-wakil rakyat di MPR/DPR merumuskannya secara lengkap. Misalnya Garis Besar Haluan Negara (GBHN) 1998 menetapkan bahwa pembangunan bidang pertanahan diharapkan untuk mendukung halhal sebagai berikut:

a) Memperkokoh persatuan dan kesatuan nasional, b) Pemberdayaan ekonomi masyarakat, c) Memperluas kesemptan berusaha serta meningkatkan lapangan kerja melalui pemerataan pemilikan tanah; d) Penguasaan dan penggunaan tanah bagi msyarakat secara adil yang didukung oleh tertib dan penegakan hukum, e) Tertib administrasi dan penggunaan tanah berdasarkan RT, RW, f) 'Menjamin keseimbangan pemanfaatan tanah secara terpadu dengan tetap menjaga kelestariannya.

Salah satu bagian guna mendukung pembangunan bidang pertanahan adalah adanya kebijaksanaan dan strategi pertanahan nasional yang konseptual,terpadu dan dapat dipahami serta memperhatikan .kepentingan semua pihak. Terutama kepentingan masyarakat dari golongan ekonomi lemah, karena dalam era reformasi ini setiap kebijaksanaan pemerintah termasuk kebijaksanaan bidang pertanahan haruslah yang menguntungkan rakyat banyak (golongan ekonomi lemah) secara langsung.

Program di atas pada dasarnya sebagai langkah konkrit yang tujuannya adalah dalam rangka meningkatkan pelayanan yang sederhana, cepat dan murah. Proyek Agraria Nasional (Pronas) menigenai sertifikasi tanah baik yang dilakukan oleh dan atas inisiatif masyarakat atau karena inisiatif Pemerintah Daerah Tingkat II, termasuk kecamatan perlu tetap dipertahankan. Sebab usaha Pronas ini, selain pemerintah memperlihatkan fungsinya dalam penertiban dan pencatatan hak untuk atas tanah secara pasti. Melainkan juga Pronas itu berfungsi sebagai usaha yang memberikan jaminan atas hak-hak masyarakat. Dengan Pronas, bukan saja kepastian hukum, bagi pemilik dapat dirasakan, melainkan juga dimungkinkan masyarakat mengambil manfaat melalui pengajuan pinjaman dengan jaminan akte tanah.

\section{Pemberdayaan Hak-hak Tanah Rakyat}

Bagaimana era reformasi memperihatkan usaha-usaha pemberdayaan terhadap hakhak atas tanah rakyat. Pemberdayaan hak rakyat atas tanah salah satunya adalah pengakuan secara hukum tentang pemilikan tanah. Upaya untuk pengakuan secara hukum dapat dilakukan dengan menggiatkan pendaftaran tanah di seluruh wilayah Indonesia, baik di pedalaman, di gunung dan juga masyarakat yang tinggal di kota-kota.

Upaya ini tentu memerlukan tenaga, biaya, dan peralatán yang-sangat besar. Padahal semua memaklumi; pemerintah sangat terbatas SDM, biaya dan peralatannya. Mengapa usaha ini mutlak diperiukan. Keterlibatan rakyat dan 
pemerintah secara bersama-sama tersebut antara lain memiliki tujuan sebagai berikut:

Pertama, adanya pengawasan langsung agar supaya kebijakan pemerintah mengenai pertanahan tidak akan terulang lagi seperti Zaman Orde Lama dan Orde Baru. Kebijakan pemerintah yang hanya menguntungkan pemilik modal asing bisa segera dihilangkan oleh karena merugikan rakyat. Pengawasan secara efektif bukan saja ditujukan bagi proses pembuatan Undang-undang, lebih penting dari itu adanya pengawasan yang ketat terhadap aktor-aktor pelaksana di lapangan. Untuk terlaksananya kesadaran tersebut, peningkatan sumber daya manusia yang profesional mutlak diperlukan, sehingga pejabat-pejabat terkait yang bermental tidak disiplin tersebut akan segera tergeser. Adapun langkah-langkah yang diperlukan dari masyarakat antara lain pendaftaran tanah menjadi tanggung jawab seluruh rakyat Indonesia pada umumnya dan pemilik tanah pada khususnya.

Kedua, usaha pemberdayaan hak-hak tanah rakyat adalah sosialisasi segala kebijakan operasional tersebut. Selama ini, segala kebijakan pertanahan hanya "berhent" di setiap kantor pertanahan. Untuk itu sangat diperlukan peran serta masyarakat dalam mensosialisasikan segala kebijaksanaan dengan jalan penyuluhan hukum. Pemerintah sendiri dalam hal ini BPN telah membentuk kelompok-kelompok masyarakat guna penyuluhan hukum pertanahan, tetapi kurang efisien. Untuk itu peran serta LSM, Perguruan Tinggi sangat diharapkan, sehingga akan muncul kesadaran masyarakat akan haknya di samping kewajibannya. ${ }^{8}$

Ketiga, kebijakan operasional dari BPN sangat diperlukan dalam pemberdayaan tanah. Terutama dengan melakukan tinjauan terhadap beberapa produk hukum Orde Baru. Guna pemberdayaan hak-hak rakyat ini pasca Orde Baru dikeluarkan beberapa ketentuanketentuan antara lain. ${ }^{9}$

Peraturan Menteri Negara Agraria/Kepala Badan Pertanahan Nasional No. 3 tahun 1998 tentang Pemanfaatan Tanah Kosong. Ketentuan dalam peraturan ini merupakan operasionalisasi dari prinsip dasar sebagaimana tercantum dalam UUPA yaitu bahwa tanah harus digunakan oleh yang berhak atas tanah selain untuk memenuhi keperluan sendiri juga tidak boleh merugikan kepentingan masyarakat. Apabila pihak yang berhak atas tanah belum dapat atau belum bermaksud mempergunakan tanahnya, baik karena belum mempunyai rencana untuk itu maupun karena menurut rencana kerjanya belum tiba saatnya untuk mengolah/ mempergunakannya, sedangkan tanah tersebut sesuai dan dapat dimanfaatkan dengan cara yang bermanfaat bagi masyarakat banyak, maka tanah tersebut tidak boleh dibiarkan kosong. Peraturan ini mewajibkan

'Suprapto Hadimulyo. 1999. "Kebijaksanaan Pertanahan dalam era Reformasi." Makalah Kuliah Umum Fakultas Hukum UII. Hilm. 7.

"Selo Soemardjan. 1984. "Landreform di Indonesia". Dalam Sediono S.P. Condronegoro. 1984 Dua Abad Penguasaan Tanah, Pola Penguasaan Tanah Pertanian di Jawa, Dari Masa ke Masa. Jakarta: PT Gramedia. HIm. 111. 
pihak yang menguasai tanah tersebut untuk memanfaatkan tanahnya dengan menanaminya tanaman pangan. Kewajiban ini juga berlaku walaupun jenis hak yang diperuntukkan bukan untuk tanaman pertanian. Kewajiban yang akan diwujudkan dengan peraturan ini adalah kebijaksanaan penggunaan tanah untuk mendukung ketahanan pangan dalam rangka mengatasi krisis pangan.

Selain itu, kebijaksanaan mengenai pemberdayaan' hak milik atas tanah tercermin dalam Peraturan Menteri Agraria/ Kepala Badan Pertanahan Nasional No. 4 tahun 1998 tentang Pedoman Penetapan Uang Pemasukan Dalam Pemberian Hak Atas Tanah Negara.

Peraturan ini merupakan pengganti dari peraturan Menteri Dalam Negeri No. 1 tahun 1975 tentang Pedoman mengenai Penetapan Uang Pemasukan, Uang Wajib Tahunan dan Biaya Administrasi yang bersangkutan dengan Pemberian hak-hak Atas Tanah Negara. Pokok-pokok kebijakan dalam peraturan inj adalah:

a. Pengurangan jumlah uang yang harus dibayar dalam perolehan, perpanjangan dan pembaharuan hak

b. Penetapan tarip uang pemasukan yang progresif untuk mendorong ke arah penguasaan tanah yang lebih merata

c. Penyederhanaan jenis pungutan

Pokok pengaturan sebagai berikut:

a. Besarnya uang pemasukan dibedakan menurut jenis dan jangka hak yang bersangkutan.

b. Untuk mengutamakan golongan ekonomi lemah pemberian hak atas tanah yang luasnya kecil (di bawah $200 \mathrm{~m} 2$ untuk tanah non pertanian dan $2 \mathrm{Ha}$ untuk tanah pertanian) uang pemasukan ditetapkan nol $\%$ atau $0,-$ (nol rupiah).

c. Tarif uang pemasukan ditentukan secara progresif untuk mendorong ke arah penguasaan tanah yang lebih merata.

d. Pungutan-pungutan lain seperti: Uang tahunan dalam HGU sumbangan pelaksanaan landreform dan uang administrasi juga dihapus.

Kebijaksanaan mengenai pemberdayaan hak atas tanah rakyat juga tercermin di dalam Peraturan Menteri Agraria/Kepala Badan Pertanahan Nasional No. 4 Tahun 1998 tentang Peraturan Hak Guna Bangunan atau Hak Pakai atas tanah untuk rumah tinggal yang dibebani hak tanggungan. Peraturan ini menegaskan ketentuan hukum dan prosedur yang berlaku dalam hal dilakukan perubahan hak atas tanah yang dibebani hak tanggungan, khususnya dilakukan pelaksana perubahan hak guna bangunan atau hak pakai menjadi hak milik berdasarkan keputusan Menteri Negara Agraria / Kepala Badan Pertanahan Nasional No. 9 Tahun 1997 Jo. No. 6 Tahun 1998 jo No. 2 Tahun 1998. Secara lebih detil pengaturan hubungan antara negara dengan masyarakat atau pengusaha dalam persoalan pemilikan dan penguasaan tanah terlihat sebagai berikut:

a) Hak Guna Bangunan atau Hak Pakai yang dibebani hak tanggungan adalah HGB atau Hak Pakai yang dijadikan jaminan perlunasan hutang dengan membebaninya dengan hak tanggungan secara sempurna yaitu sudah dibuat Akte pemberian Hak Tanggungannya (APHT) dan sudah didaftarkan serta dikeluarkan sertifikat hak tanggungannya. Dalam hal ini penjaminan 
HGB atau Hak Pakai itu hanya dilakukan dengan pembuatan Surat Kuasa Membebankan Hak Tanggungan (SKMHT), maka perubahan hak tersebut menjadi hak milik tidak memerlukan persetujuan formal dari pemegang Hak Tanggungan. Sudah cukup apabila kepada Kantor Pertanahan diserahkan sertifikat Asli HGB atau Hak Pakai yang bersangkutan. Dalam hal demikian maka "peminjaman" sertifikat tersebut dari bank untuk keperluan perubahan hak dapat didahului dengan pembuatan surat kuasa membebankan Hak Tanggungan (SKMHT).

b) Penghapusan Hak Tanggungan berhubungan dengan hapusnya Hak Milik atau Hak Pakai yang dijamin dilakukan oleh Kepala Kantor Pertanahan karena jabatan. Oleh karena itu untuk keperluan ini tidak diperlukan lagi surat permohonan atau surat persetujuan khusus dalam bentuk persetujuan atau sejenisnya. Langkah ini adalah sesuai dengan ketentuan Pasal 122 ayat (4) dan ayat (6) Peraturan Menteri Negara Agraria/Kepala Badan Pertanahan Nasional No. 3 Tahun 1997.

Kebijakan hukum yang langsung meningkatkan pemberdayaan hak milik atas tanah dapat ditihat dalam Keputusan Menteri Agraria:

1. Keputusan Menteri Negara Agraria/Kepala Badan Pertanahan Nasional No. 9 Tahun 1997 jo No. 15 Tahun 1997 jo. No. 1 Tahun 1998 tentang pemberian Hak Milik Atas Tanah untuk RS/RSS. Dengan keputusan tersebut Hak Guna Bangunan Atas Tanah untuk RS dan RSS di atas tanah negara, termasuk di atas Hak Pengelolaan, kepunyaan perorangan warga negara indonesia, atas permohonan pemegang hak atau kuasanya dirubah menjadi Hak Milik. Kriteria:

a harga perolehan tanah tidak lebih dari Rp. 30,000,000,00 (tiga puluh juta).

b di atasnya telah dibangun rumah dalam rangka pembangunan perumahan massal atau komplek perumahan.

yang dimaksudkan perubahan hak adalah penetapan mengenai penegasan bahwa sebidang tanah yang semula dipunyai dengan HGB atas permohonan pemegang haknya menjadi tanah negara dan sekaligus memberikan tanah tersebut kepadanya dengan Hak Milik.

2. Keputusan Menteri Agraria/Kepala Badan Pertanahan Nasional No. 2 Tahun 1998 tentang Pemberian Atas Tanah yang dibeli dari pemerintah oleh Pegawai Negeri dan Pemerintah dengan keputusan ini maka:

a Tanah untuk rumah tinggal yang telah dibeli oleh pegawai negeri dari pemerintah telah dilunasi harganya, diberikan kepada pegawai negeri yang bersangkutan dengan Hak Milik.

b Hak Guna Bangunan atau Hak Pakai atas tanah yang berasal dari tanah untuk rumah tinggal yang telah dibeli oleh pegawai negeri dari pemerintah dan masih atas nama pegawai negeri yang bersangkutan atau ahli warisnya, atas permohonan yang bersangkutan dihapus dan diberikan kembali kepada bekas pemegang haknya dengan Hak Milik. 
c Hak Guna Bangunan atau Hak Pakai atas tanah yang berasal dari tanah untuk rumah tinggal yang dibeli oleh pegawai negeri dari pemerintah yang sudah habis jangka waktunya dan masih atas nama pegawai negeri yang bersangkutan atau ahli warisnya atas permohonan yang bersangkutan dihapuskan dan diberikan kembali kepada bekas pemegang haknya dengan Hak Milik. .

3. Tentang pemberian Hak Milik Atas Tanah untuk Rumah Tinggal. Dengan keputusan ini:

a) Hak Guna Bangunan atau Hak Pakai atas tanah untuk Rumah Jinggal kepunyaan perseorangan warga negara Indonesia yang luasnya 600 $\mathrm{m} 2$ atau kurang atas permohonan yang bersangkutan dihapus dan diberikan kembali. kepada'bekas pemegang haknya dengan Hak Milik.

b) Hak Guna Bangunan atau. Hak Pakai atas Tanah Rumah Tinggal kepunyaan perseorangan warga negara Indonesia yang luasnya $600 \mathrm{~m} 2$ atau kurang yang sudah habis. jangka waktunya dan masih dipunyai oleh bekas pemegang hak tersebut, atas permohonan yang bersangkutan dihapus dan diberi kembali kepada bekas pemegang haknya dengan Hak Milik.

4 Keputusan Menteri Agraria/Kepalà Badan Pertanahan Nasional No. 3 Tahun 1999 No. 3 Tahuri 1999. Dengan Keputùsan' ini ada perubahan yang cukup mendasar bagi pengurusan hak-hak atas tanah.
Dalam SK ini ada pelimpahan wewenang yang lebih besar kepada daerah Tingkat II dengan Tingkat I dalam hal pemberian Hak Milik dan Hak Guna Bangunan serta Hak Pakai.

Berdasarkan uraian di atas, jelaslah kebijakan pemerintah dalam era reformasi sungguh berbeda. Perbedaan tersebut terlihat bukan sajá dalam kaitannya dengán adanya pergantian peraturan perundangan yang lebih menyederhanakan esensi hukum yang ada di dalam UUPA Tahun 1960. Melainkan juga pengaturan jaminan pemerintah terhadap rakyat melalui GBHN 1998 diikuti oleh keputusan terlihat seiring dan konsisten. Apakah dalam penerapannya juga akan sama tentu masih menunggu kesediaan petugaspetugas yang mau meningkatkan kedisiplinan kerja yang profesional.

\section{Simpulan.}

Dari tulisan di atas dapat ditarik kesimpulan bahwa dasar-dasar pembentukan hukum agraria nasional telah diletakkan oleh penguasa Orde Lama: Hukum agraria ini secara konseptual mempunyai arah untuk mewujudkan masyarakat yang sejahtera berdasarkan Pancasila dan UUD 1945 khususnya masyarakat tani. Kebijakan konkrit penguasa Orde Lama untuk mewujudkan masyarakat tersebut telah dikeluarkan, tapi operasionalnya masih belum mewujudkan hasil yang optimal Hambatan yang ditemui, bukan saja bersifat politis seperti konflik parpol yang bègitu kuat, jugà kesadaran hukum masyarakăt akan hak-hak tanah belùm begitu penting. Kebijakan sèrta arah yang sudah dicanangkañ oleh Orde Lama tersèbüt, mulai digeser/diletakkan oleh penguasa Orde 
Baru. Akan tetapi, situasi pemilikan dan penguasaan tanah, khususnya bagi masyarakat telah terabaikan, salah satu sebabnya adalah pemerintahan Orde Baru mengutamakan pertumbuhan ekonomi yang ditopang oleh kehadiran modal asing. Akibatnya kebijakankebijakan pemerintah diarahkan untuk kepentingan para pemilik modal dengan mengesampingkan hak-hak rakyat kecil. Hakhak rakyat yang kebanyakan tidak terjamin kepastian hukumnya menjadi bulan-bulanan para pemilik modal. Sementara pejabatpejabat tertentu telah diuntungkan leh situasi penguasaan tanah yang semakin komoditas.

Dengan lengsernya rezim Orde Baru, disusul lahirnya penguasa Orde Reformasi, barulah diketahui bahwa pertumbuhan ekonomi yang dijadikan panglima penguasa Orde Baru ternyata hanya menguntungkan segelintir orang / kelompok. Untuk itu pada zaman Reformasi ini, di mana supremasi hukum yang menjadi panglimanya, maka untuk memberdayakan hak-hak rakyat, perlu adanya perlindungan dan jaminan kepastian hukum atas hak-hak tanah rakyat. Perlu dicatat pandangan Selo Soemardjan bahwa landform ini berhasil atau tidaknya tergantung kepada kecakapan administrasi desa, yang umumnya kurang terlatih dan khususnya juru tulis, untuk melaksanakan pekerjaan birokratis yang banyak dan khusus. Keluarnya kebijakan hukum melalui GBHN 1998 termasuk, timbulnya kebijakan baru yang dikeluarkan oleh Ditjen Agraria, telah benar-benar memperlihatkan aspek-aspek kesejahteraan rakyat lebih utama. Selain penguasaan tanah diberikan kepada pengusaha besar, hanya saja batasannya lebih tegas. Karena itu dalam era reformasi jaminan kepastian hukum ini diharapkan para pemegang hak dapat dengan aman dan tenang dalam menikmati haknya sesuai dengan penggunaan dan peruntukannya. Amin.

\section{Daftar Pustaka}

Hermawan Sauni (ed) 1998. Parlindungan Hukum Agraria, Beberapa Pemikiran dan Gagasan. Medan: USU.

Budi Harsono. 1994. Hukum Agraria; Sejarah Pembentukan UUPA Isi dan Pelaksanaannya. Jakarta: Djambatan.

Hadisuprapto. 1977. Ikhtisar Perkembangan Hukum Tanah DIY. Yogyakarta: Karya Kencana.

Maria R Ruwiastuti, dkk. Penghancuran Hak Masyarakat Adat atas Tanah. Bandung: INPI-PACT.

Jawahir Thontowi. "Reformasi dan Kompilasi Peraturan Hukum Kerukunan antara Umat Beragama." di dalam Hanafi Sofyan. 1995. Indonesia dalam Transisi: Canbera: Halmahera Fondation. HIm. 168.

Suprapto Hadimulyo, 1999. "Kebijaksanaan Pertanahan dalam era Reformasi." Makalah Kuliah Umum Fakultas Hukum UII.

Selo Soemardjan. 1984. "Landreform di Indonesia". Dalam Sediono S.P. Condronegoro. 1984 Dua Abad Penguasaan Tanah, Pola Penguasaan Tanah Pertanian di Jawa, Dari Masa ke Masa. Jakarta: PT Gramedia.

Badan Pertanahan Nasional. Jakarta: Dasawarsa Bhumi Bhakti Adhiguna. 